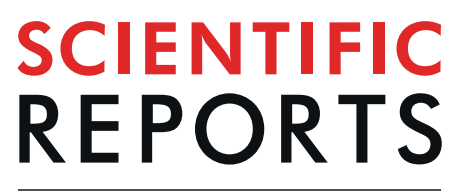

natureresearch

\title{
OPEN Biochar amendment improves degraded pasturelands in Brazil: environmental and cost-benefit \\ analysis
}

Received: 15 January 2019

Accepted: 8 July 2019

Published online: 19 August 2019
Agnieszka E. Latawiec ${ }^{1,2,3,4,5}$, Bernardo B. N. Strassburg $\mathbb{D}^{1,2,6}$, André B. Junqueira ${ }^{1,2,12}$, Ednaldo Araujo7, Luiz Fernando D. de Moraes ${ }^{7}$, Helena A. N. Pinto ${ }^{1,2,6}$, Ana Castro ${ }^{1,2}$, Marcio Rangel ${ }^{2}$, Gustavo A. Malaguti ${ }^{1,2}$, Aline F. Rodrigues ${ }^{1,2}$, Luis Gustavo Barioni ${ }^{9}$, Etelvino H. Novotny ${ }^{10}$, Gerard Cornelissen ${ }^{11}$, Maiara Mendes ${ }^{1,2,3}$, Nilcileny Batista ${ }^{8}$, Jose Guilherme Guerra7, Everaldo Zonta ${ }^{8}$, Catarina Jakovac ${ }^{2}$ \& Sarah E. Hale ${ }^{11}$

Most deforested lands in Brazil are occupied by low-productivity cattle ranching. Brazil is the second biggest meat producer worldwide and is projected to increase its agricultural output more than any other country. Biochar has been shown to improve soil properties and agricultural productivity when added to degraded soils, but these effects are context-dependent. The impact of biochar, fertilizer and inoculant on the productivity of forage grasses in Brazil (Brachiaria spp. and Panicum spp.) was investigated from environmental and socio-economic perspectives. We showed a $27 \%$ average increase in Brachiaria production over two years but no significant effects of amendment on Panicum yield. Biochar addition also increased the contents of macronutrients, soil $\mathrm{pH}$ and CEC. Each hectare amended with biochar saved 91 tonnes of $\mathrm{CO}_{2}$ eq through land sparing effect, 13 tonnes of $\mathrm{CO}_{2}$ eq sequestered in the soil, equating to $\mathrm{U} \$ 455$ in carbon payments. The costs of biochar production for smallholder farmers, mostly because of labour cost, outweighed the potential benefits of its use. Biochar is $617 \%$ more expensive than common fertilizers. Biochar could improve productivity of degraded pasturelands in Brazil if investments in efficient biochar production techniques are used and biochar is subsidized by low emission incentive schemes.

Land covered with forage grasses for animal grazing occupies $26 \%$ of global ice-free land ${ }^{1}$ and livestock provides employment and sustenance to nearly one third of the world's population. Pasturelands contribute significantly (40\%) to global agriculture gross domestic product ${ }^{2}$. Inadequate management of pastures and soil degradation throughout the tropics renders pasture productivity below its potential and lead to adverse economic

${ }^{1}$ Department of Geography and the Environment, Rio Conservation and Sustainability Science Centre, Pontifical Catholic University of Rio de Janeiro, 22453900, Rio de Janeiro, Brazil. ${ }^{2}$ International Institute for Sustainability, Estrada Dona Castorina 124, 22460-320, Rio de Janeiro, Brazil. ${ }^{3}$ National School of Tropical Botany (ENBT), Rua Pacheco Leão, 2040 - Solar da Imperatriz, Horto, 22460-036, Rio de Janeiro, Brazil. ${ }^{4}$ Institute of Agricultural Engineering and Informatics, Faculty of Production and Power Engineering, University of Agriculture in Kraków, Balicka 116B, 30-149, Kraków, Poland. ${ }^{5}$ University of East Anglia, Norwich Research Park, Norwich, NR4 7TJ, UK. ${ }^{6}$ Federal University of Rio de Janeiro, 68020, Rio de Janeiro, Brazil. ${ }^{7}$ Brazilian Agricultural Research Corporation, Embrapa Agrobiology, Rodovia BR 465, Km 7, 23891-000, Seropédica, Rio de Janeiro Brazil Embrapa Agrobiology, Rio de Janeiro, Brazil. ${ }^{8}$ Federal Rural University of Rio de Janeiro (UFRRJ), Rodovia BR 465, Km 07, 23890-000, Seropédica, Rio de Janeiro, Brazil. ${ }^{9}$ Brazilian Agricultural Research Corporation, Embrapa Agricultural Informatics, Av. Dr. André Tosello, 209 - Cidade Universitária, 13083-886, Campinas, São Paulo, Brazil. ${ }^{10}$ Brazilian Agricultural Research Corporation, Embrapa Soils, R. Jardim Botânico, 1024 - Jardim Botânico, 22460-000, Rio de Janeiro, RJ, Brazil. ${ }^{11}$ Department of Environmental Engineering, Norwegian Geotechnical Institute, P.O. Box 3930, Ullevål Stadion, N-0806, Oslo, Norway. ${ }^{12}$ Institut de Ciència i Tecnologia Ambientals, Universitat Autònoma de Barcelona, 08193, Bellatera, Barcelona, Spain. Correspondence and requests for materials should be addressed to A.E.L. (email: a.latawiec@iis-rio.org) 
and environmental impacts ${ }^{3,4}$. In Brazil, the country that holds the world's largest commercial cattle herd ${ }^{1,5}$, pasture-fed cattle ranching occupies 158 million hectares corresponding to $75 \%$ of the country's agricultural land $^{3}$. Brazilian cattle ranching is characterized by low stocking rates, mostly below 1 animal unit (AU) per hectare $\left(1 \mathrm{AU}=0.7\right.$ animal), a rather low number comparing with other meat-producing countries ${ }^{3}$. Labour cost, shortage of qualified technical extension assistants and high costs to maintain good quality of soils are among principal reasons for low productivity of Brazilian cattle ranching ${ }^{3,5-7}$. Overgrazing, erosion and land availability that historically hurdled application of good agricultural practices contributed to the prevalence of land degradation in Brazil ${ }^{5}$. More than $70 \%$ of pastures in Brazil are classified as degraded ${ }^{8}$.

Degraded Brazilian pasturelands have impacts beyond the country level. Together with agriculture, they are linked to deforestation and biodiversity loss at an unprecedented scale, and greenhouse gases emissions of global significance 9 . If projections are realized, Brazil will see the highest worldwide increase in meat production in the following decade ${ }^{10}$. To avoid negative impacts of expanding cattle ranching, improving productivity of already converted lands has been proposed as a key solution to conciliate development with conservation ${ }^{11}$. In Brazil, pastureland productivity could be tripled in much more sustainable ways ${ }^{3}$, providing meat and other commodities while reversing environmental degradation. This is particularly important for smallholders who represent the majority (70\%) of cattle ranchers in Brazil and often strive to maintain profits. In addition, the Brazilian Native Vegetation Protection Law and governmental commitments ${ }^{12}$ oblige producers to spare land for conservation. This may generate competition for land as many producers strive to continue with low-productivity cattle ranching to meet the ever-increasing national and international demands for meat, while simultaneously seeking to keep a part of their land covered with native vegetation. Legally imposed restoration is projected to occur throughout Brazilian biomes with the Atlantic Rainforest biome expected to restore the largest areas ${ }^{13,14}$ (Supplementary Fig. S1). The Atlantic Rainforest biome is a global biodiversity hotspot, concentrating $95 \%$ of the Brazilian population and $80 \%$ of the national Gross Domestic Product.

Pasture degradation in the Atlantic Forest biome has a range of direct negative impacts on the provision of ecosystem services, such as water and food production, and carbon sequestration. Despite being a fundamental resource for human well-being and being increasingly recognised in environmental policies ${ }^{15}$, soil ecosystem services remain poorly understood, overlooked and largely excluded from the studies on ecosystem services valua$\operatorname{tion}^{16}$. Loss of soil carbon is at the heart of land degradation; both in terms of increasing carbon dioxide emissions to the atmosphere and of the damage it does to soil physical, chemical and biological attributes. Including the valuation of soil ecosystem services into decision making is not only paramount for minimizing carbon emissions, but also for improving local livelihoods and promoting food security.

Biochar (a carbon-rich product resulting from the pyrolysis of organic residues) has emerged as a potential solution to restore soils, increase agricultural performance and sequester carbon ${ }^{17}$. Biochar was shown to improve soil $\mathrm{pH}$, nutrient content and water holding capacity ${ }^{18}$; applied alone or combined with limestone or inoculant ${ }^{19,20}$. Biochar is often accompanied by ash that is rich in macronutrients such as $\mathrm{Ca}, \mathrm{Mg}, \mathrm{K}$, important for soil health ${ }^{21}$. Slavich et al. $(2013)^{22}$ showed that biochar from feedlot manure increased pasture productivity by $11 \%$ and improved the agronomic nitrogen use efficiency by 23\%. A meta-analysis has been carried out based on 128 observations of biochar decomposition in soil. A mean residence time of labile and recalcitrant biochar carbon pools were reported to be 108 days and 556 years respectively. Three percent of the biochar carbon was contained in the labile pool. Biochar was also shown to retard the mineralisation of soil organic matter and stimulate microbial activity ${ }^{23}$. Studies that investigate the potential of biochar to improve forage grass productivity and diminish adverse impacts of cattle ranching are however scarce.

This study investigates biochar amended to Brazilian pasturelands with the aim of increasing yield of the two most common forage grasses in Brazil; Brachiaria brizantha cv. Marandu and Panicum maximum cv. Mombaça. Biochar may present an interesting alternative in pasture management in Brazil as farmers use charred organic residues (so called 'moinha') to increase soil carbon, nutrients and correct $\mathrm{pH}$. It is also common in rural areas of Brazil to burn organic residues. Introducing simple stoves for biochar production from these residues could reduce risks related uncontrolled fire spread and health issues (Supplementary Video S1). Pot trials in controlled conditions for six harvest cycles, a field study over two harvest cycles, and a socio-economic survey were carried out and provided the most comprehensive up-to-date analysis of biochar use in Brazilian pasturelands. This study has three main aims: (1) investigate the impacts of biochar on forage yield and soil properties; (2) perform a socio-economic analysis of biochar use in small-holder organic farming; (3) valuation of ecosystem services related to food production and carbon sequestration that result from biochar amendment to soil (case study for the state of Rio de Janeiro). To the best of our knowledge this is the first study that investigates the use of biochar in Brazilian pastures, one of the very few worldwide studies on biochar amendment to pastureland, and the first study to report a socio-economic analysis of biochar amendment to improve sustainability of cattle ranching.

\section{Methods}

Study site. The pot experiment was performed in a greenhouse $\left(22.97^{\prime} \mathrm{S}, 43.24^{\prime} \mathrm{W}\right)$ where the temperature was recorded daily and watering frequency and dose were adjusted to reflect field conditions. The field experiment was performed at the Brazilian Agricultural Research Corporation (Embrapa Agrobiologia $-22^{\circ} 45^{\prime} \mathrm{S}$; $43^{\circ} 41^{\prime} \mathrm{W}$ ). Pot experiments and field trials were carried out in Rio de Janeiro, Brazil. Additional site information is included in Supplementary methods and Supplementary Fig. S2. Experiments were conducted on soil classified as Planosol $^{24}$.

Experimental design and pasture management. Tested forage grasses were Brachiaria and Panicum. A full factorial design was delineated $\left(2^{3}\right.$ for Brachiaria and $2^{2}$ for Panicum) with or without: inoculant (Azospirillum brasilense strain sp. 245; used only for Brachiaria); fertilizer (562 kg termophosphate per hectare with $18 \%$ of $\mathrm{P}_{2} \mathrm{O}_{5}$ $(100 \mathrm{~kg} / \mathrm{ha})$ and potassium sulphate with $50 \%$ of $\mathrm{K}_{2} \mathrm{O}(120 \mathrm{~kg} / \mathrm{ha})$; and biochar $(15 \mathrm{t} / \mathrm{ha})$. Control did not include 
amendments. Inoculum ( $50 \mathrm{~g}$ for each $10 \mathrm{~kg}$ of seeds) was produced with turf and contained 108 colony-forming units/g. A $10 \%$ sucrose solution was used as an adherent. In the pot experiment, grasses were originally sown on soil collected from field experiment at a density of 10 seeds/pot for Brachiaria and 12 seeds/pot for Panicum in $10 \mathrm{~L}$ pots, as recommended by the seed provider. Posteriorly, four plants were maintained per pot in order to standardize the experiment. Biochar, fertilizer and/or inoculant were mixed at the top $10 \mathrm{~cm}$ of the pots. Each treatment was replicated five times for each grass and aboveground biomass was harvested and measured six times during 15 months $(68,139,207,269,361$ and 454 days after sowing, starting February 2015). In the field, 40 plots $(2 \mathrm{~m} \times 2 \mathrm{~m}$ each) were established in May 2014 in a randomized block experimental design. Brachiaria was sowed at a density of 20 seeds/plot and Panicum at 55 seeds/plot. Initially, plots were homogenously irrigated to facilitate pasture establishment and prevent possible germination problems due to a severe drought at the beginning of the experiment. Biochar, fertilizer and/or inoculant were spread on soil surface and incorporated manually into soil to approximately $10 \mathrm{~cm}$ of depth. Each treatment was replicated three times for Brachiaria and four times for Panicum, and the biomass was harvested twice for Brachiaria (95 and 170 days after sowing) and three times for Panicum (95, 143 and 214 days after sowing).

Biochar production. In Seropédica, the species Gliricidia sepium (family Fabaceae) is invasive and must be systematically cut, providing large amounts of organic residues. Gliricidia has a high biomass production capacity in various tropical conditions up to $800 \mathrm{~m}$ altitude. Being a perennial and easily cultivated plant for green manuring ( $\mathrm{N}$ fixation) and mulching, Gliricidia’s thicker stalks can be used for biochar production as they do not have alternative use and may cause undesired shadow. Gliricidia tolerates frequent pruning of about four times per year. Therefore, this biomass feedstock was chosen for biochar production and can be transferrable to other tropical conditions. Traditional brick kiln ${ }^{25}$ was used, since it presents desirable-quality biochar. The analysis of physicaland chemical biochar properties (Supplementary Fig. S3) followed the methods described in Martinsen et al. ${ }^{26}$.

Biomass analysis. In the pot experiment and field trial, the analysis of grass aboveground biomass included measuring wet and dry weights as well as macro and micronutrients. Aboveground biomass was weighed after harvest (leaving $5 \mathrm{~cm}$ of forage for regrowth) for wet weight, and again after drying in the oven for 96 hours (at $60^{\circ} \mathrm{C}$ ) for dry weight. After each harvest, a leaf sample of about $200 \mathrm{~g}$ was collected, from which the concentration of macronutrients ( $\mathrm{P}, \mathrm{K}, \mathrm{Ca}, \mathrm{Mg}$ and $\mathrm{S}$, in $\mathrm{g} / \mathrm{kg}$ ) and micronutrients $(\mathrm{Cu}, \mathrm{Fe}, \mathrm{Mn}$ and $\mathrm{Zn}$, in $\mathrm{mg} / \mathrm{kg}$ ) were measured following the protocol of Malavota et al. ${ }^{27}$. Sulfuric acid digestion was used to analyze N. Roots were analyzed at the end of the pot experiments (Supplementary methods).

Soil sampling and analysis. For pot experiments, soil samples were collected and analyzed at the beginning and at the end of the experiment (February 6, 2015 and May 5, 2016). In the field trial, soil samples were collected at the end of each harvest cycle (dates in Supplementary Methods). Five subsamples along two diagonal lines through each plot were collected and pooled into one composite sample. Soil samples were homogenized and sieved to $2 \mathrm{~mm}$, and analyzed for $\mathrm{pH}\left(\mathrm{H}_{2} \mathrm{O}, \mathrm{KCl}\right.$ and $\left.\mathrm{CaCl}_{2}\right)$, plant-available water (difference between water retention at 0.10 and $15 \mathrm{~atm}$, i.e., $\mathrm{pF} 2$ and 4.2, respectively), organic matter (dag/ $/ \mathrm{kg})$, total N (g/kg), total $\mathrm{K}(\mathrm{mg} /$ $\left.\mathrm{dm}^{3}\right)$, total $\mathrm{P}\left(\mathrm{mg} / \mathrm{dm}^{3}\right), \mathrm{P}$ residual $(\mathrm{mg} / \mathrm{L})$, total $\mathrm{Mg}\left(\mathrm{cmol} / \mathrm{dm}^{3}\right), \mathrm{H}+\mathrm{Al}\left(\mathrm{cmol} / \mathrm{dm}^{3}\right), \mathrm{Na}\left(\mathrm{mg} / \mathrm{dm}^{3}\right), \mathrm{Ca}(\mathrm{cmol} /$ $\left.\mathrm{dm}^{3}\right), \mathrm{SB}\left(\mathrm{cmol} / \mathrm{dm}^{3}\right)$, CEC (effective and potential; $\left.\mathrm{cmol} / \mathrm{dm}^{3}\right), \mathrm{Zn}\left(\mathrm{mg} / \mathrm{dm}^{3}\right), \mathrm{Fe}\left(\mathrm{mg} / \mathrm{dm}^{3}\right), \mathrm{v}(\%), \mathrm{m}(\%), \mathrm{Mn}$ $\left(\mathrm{mg} / \mathrm{dm}^{3}\right), \mathrm{Cu}\left(\mathrm{mg} / \mathrm{dm}^{3}\right)$ and soil texture. Residual $\mathrm{P}$, organic matter, $\mathrm{Zn}, \mathrm{Cu}, \mathrm{Mn}$ and Fe were determined using Mehlich method. C, $\mathrm{H}$ and $\mathrm{N}$ percent in the pot experiment was determined using Dumas method via dry combustion of $5.0 \mathrm{mg}( \pm 0.1 \mathrm{mg})$ soil in an element analyzer, PerkinElmer 2400. Acetanilide was used as reference material. For more information check Supplementary Methods.

Statistical analysis. Aboveground biomass weight data were analyzed using repeated measures linear mixed effect models, using 'time' (i.e., the different harvests through time), and the treatments: biochar, fertilizer, inoculant and their interactions as fixed factors and 'subject' (i.e., each pot or plot) as a random (blocking) factor. Root biomass weight data were analyzed using generalized linear models, since these data were obtained at a single time (at the end of the pot experiment). For the analyses of multivariate data (biomass nutrient concentration and soil parameters), we first performed Principal Components Analyses (PCAs) on each dataset (after centering and standardizing the variables) and then used the first two axes (or principal components) in further analyses. For the pot experiment, PCA axes were used as dependent variables in either repeated measures linear mixed effect models (for biomass nutrient concentration, given that this data was measured several times through time) or in generalized linear models (for soil parameters, given that this was measured only at the end of the pot experiment), with the same structure as the models described above. For the field trials, PCA axes were used as dependent variables in repeated measures linear mixed effect models for both biomass nutrient concentration and for soil parameters (given these variables were repeatedly measured in time). All analyses were performed in $\mathrm{R}^{28}$, using packages stats, $l m e 4^{29}$ and $M u M I n^{30}$.

Cost-benefit analysis and ecosystem services valuation. Two ecosystem services were valuated: food provision and carbon sequestration. To calculate food production, biomass from each treatment was compared with the control (Supplementary Methods - Meat profit calculation from biomass). This value was used to calculate the additional US $\$$ /ha for each treatment estimated from the additional potential beef production, using Equation (1).

$$
M=\Delta B \times r \times f \times p,
$$

in which:

$\mathrm{M}=$ additional profit meat 
$\Delta \mathrm{B}=$ difference of the biomass generated with the treatment in relation to the control;

$r=0.026=$ value of the equivalent ton of carcass per ton of dry mass ingested, in a modal system with a complete cycle of meat production for the Atlantic Forest, with an efficiency rate of $100 \%{ }^{31}$

$\mathrm{f}=$ forage productivity, value of minimum or maximum productivity (between 10 and $17 \mathrm{tDM} / \mathrm{ha}$ ) of the grass Brachiaria cv. Marandu, in $\mathrm{tDM} / \mathrm{ha}^{32}$;

$\mathrm{p}=$ meat price, in US\$, the average price of meat in the State of Rio de Janeiro during the experiment period at the producer level was $\mathrm{R} \$ 9.42 / \mathrm{kg}^{33}$ and the exchange rate, $\mathrm{R} \$ 3.51 / \mathrm{US} \$$.

For carbon sequestration, land sparing effects and direct carbon storage in soil adding biochar were evaluated. Land sparing assumes that for each hectare with improved productivity, a proportion of land will be freed up for other uses ${ }^{3}$. In the Atlantic Forest, the carbon saved is $443.7 \mathrm{tCO}_{2} \mathrm{eq} / \mathrm{ha}$. This was multiplied by land spared by intensification with biochar $(27 \%)$ and by the unit carbon price (US $\$ 5 / \mathrm{tCO}_{2} \mathrm{eq}$ ). The value of carbon sequestered in soil was obtained from the weight balance determined in the pot experiment (more information in Supplementary Table S1).

The cost of biochar production in different stoves was estimated from equipment and labour costs through field research (all details in Supplementary Table S2, S3 and S4; Supplementary Methods). According to Brazilian labour law, an employee can work up to 44 hours/week, being 8 hours a day. These values were considered in our research.

The analysis was carried out for scenarios with and without labour costs. Cost of production in each additional kiln was calculated considering that kilns can be operated in parallel. Cost-benefit analysis of biochar, fertilizer and inoculant were calculated. Following costs were taken into account: fertilizer (U\$ $0.3 / \mathrm{kg}$ for thermophosphate and U\$6/kg for potassium sulphate), transportation (IEA/SP) ${ }^{34}$, inoculant (U\$0.45/g) and lime (U\$0.02/ $\mathrm{kg}$ ) (other details, Supplementary Methods).

The minimum carbon price was calculated (Supplementary Methods and Supplementary Table S5). Finally, to make biochar economically viable, three different scenarios were considered: (a) biochar in the soil only during the experiment period, (b) biochar reduction, in a linear tendency, until zero at the end of 10 years and (c) the same gain with biochar for 10 years, without any loss. For each scenario, net present value (NPV) was calculated based on meat production gains, using the attractiveness rate of $6 \%$. The resulting values were divided by the amount of carbon sequestered in each hectare.

\section{Results}

Forage productivity and nutrient content. In the pot experiment, the addition of either biochar or fertilizer led to a significant increase in aboveground biomass of Brachiaria in all harvests (both dry and fresh biomass; Fig. 1 and Table 1 and 2; biochar, dry biomass: $\mathrm{F}=6.57, \mathrm{p}=0.015$; biochar, fresh biomass: $\mathrm{F}=11.98$, $\mathrm{p}=0.002$; fertilizer, dry biomass: $\mathrm{F}=4.37, \mathrm{p}=0.045$; fertilizer, fresh biomass: $\mathrm{F}=4.23, \mathrm{p}=0.048$ ). There was a significant interaction between inoculant and time (dry biomass: $F=2.34, p=0.045$; fresh biomass: $F=2.9$, $\mathrm{p}=0.015$ ), and in general inoculant negatively impacted aboveground biomass production in most harvests (Table 2). For dry aboveground biomass, we also observed a significant interaction between biochar and fertilizer $(\mathrm{F}=4.24, \mathrm{p}=0.048)$, in which the treatment where these two were combined showed an intermediate level of productivity between biochar only (highest) and fertilizer only (lowest; Table 2). For Panicum, there was a significant interaction between biochar and time (dry biomass: $\mathrm{F}=8.87, \mathrm{p}<0.001$; fresh biomass: $\mathrm{F}=12.51, \mathrm{p}<0.001$ ), fertilizer and time (dry biomass: $\mathrm{F}=2.84, \mathrm{p}=0.021$; fresh biomass: $\mathrm{F}=4.48, \mathrm{p}=0.001$ ), as well as a third order interaction between these three variables (dry biomass: $F=4.74, p=0.001$; fresh biomass: $F=6.61, p<0.001$; Table 1), indicating a much less consistent and unstable effect of these variables over time on grass productivity. For this forage grass, biochar or fertilizer had strong positive effect in the first harvest, but this effect tended to disappear, and even invert, with time (Fig. 1c,d). Considering the relative differences between treatments and control in aboveground biomass (Table 2), the largest cumulative difference was for biochar for Brachiaria (27\%) and a combination of biochar with fertilizer for Panicum (25.5\%). Regarding the root biomass measured at the end of the pot experiment, we found no effects of treatments nor of their interactions on root dry or fresh biomass, for both grasses (Supplementary Table S6). In the field trials, we did not observe statistically significant effects of the treatments on aboveground biomass productivity for both grasses (Fig. 2; Supplementary Tables S7).

Figure 3 presents the results of a Principal Components Analysis (PCA) of biomass nutrient content for the pot experiment for Brachiaria and Panicum. Loadings of the variables included in the PCA are in Supplementary Table S8. The first axis of the PCA (PC1) explained $29.1 \%$ of the variation in the dataset, and was positively correlated mainly with N, P and Mg (Fig. 3; Supplementary Table S8). The second axis (PC2) explained 26.8\% of the variation and was correlated positively with $\mathrm{K}$ and negatively with $\mathrm{Ca}, \mathrm{Mn}$ and $\mathrm{Zn}$ (Fig. 3, Supplementary Table S8). The effect of biochar amendment is clearly observed on axis PC2 (Brachiaria: $\mathrm{F}=327.9, \mathrm{p}<0.001$; Panicum: $\mathrm{F}=357.09, \mathrm{p}<0.001$ ), given that the leaves of plants of both grasses growing on biochar-enriched substrates tended to have higher concentrations of $\mathrm{K}$ but lower of $\mathrm{Mn}$ and $\mathrm{Zn}$ (Fig. 3). Biochar had also a significant effect on axis PC1 (Brachiaria: $\mathrm{F}=49.23$, $\mathrm{p}<0.001$; Panicum: $\mathrm{F}=70.43, \mathrm{p}<0.001$; Supplementary Table S9), because treatments with biochar tended to reach lower concentrations of nutrients such as $\mathrm{N}, \mathrm{Mg}$ and $\mathrm{Ca}$, which are strongly related to axis PC1. Fertilizer had also a significant effect on axis PC2 (F $=16.94$, $\mathrm{p}<0.001$ ) (Supplementary Table S9), although only for Brachiaria, indicating that the addition of fertilizer tended to increase leaf concentrations of N, P and Mg. The significant interactions between treatments and time (harvest; Supplementary Table S9) resulted from the expected strong temporal variation in leaf nutrient concentration, stemming from the fact that plants absorbed soil nutrients and grew in biomass at different rates through time (Fig. 2). When analyzed individually, most of the nutrients (7 out of $10: \mathrm{N}, \mathrm{P}, \mathrm{Ca}, \mathrm{Mg}, \mathrm{Mg}, \mathrm{S}, \mathrm{Cu}, \mathrm{Fe}$ ) in the biomass of both grasses followed similar patterns: relatively lower concentrations in the first harvest cycle, increasing over the second, third and fourth cycles, and diminishing towards the end of the experiment. Regarding the analyses of nutrient content in the root biomass in the pot experiment, we did not find any effect of treatments nor of 
Yield per harvest
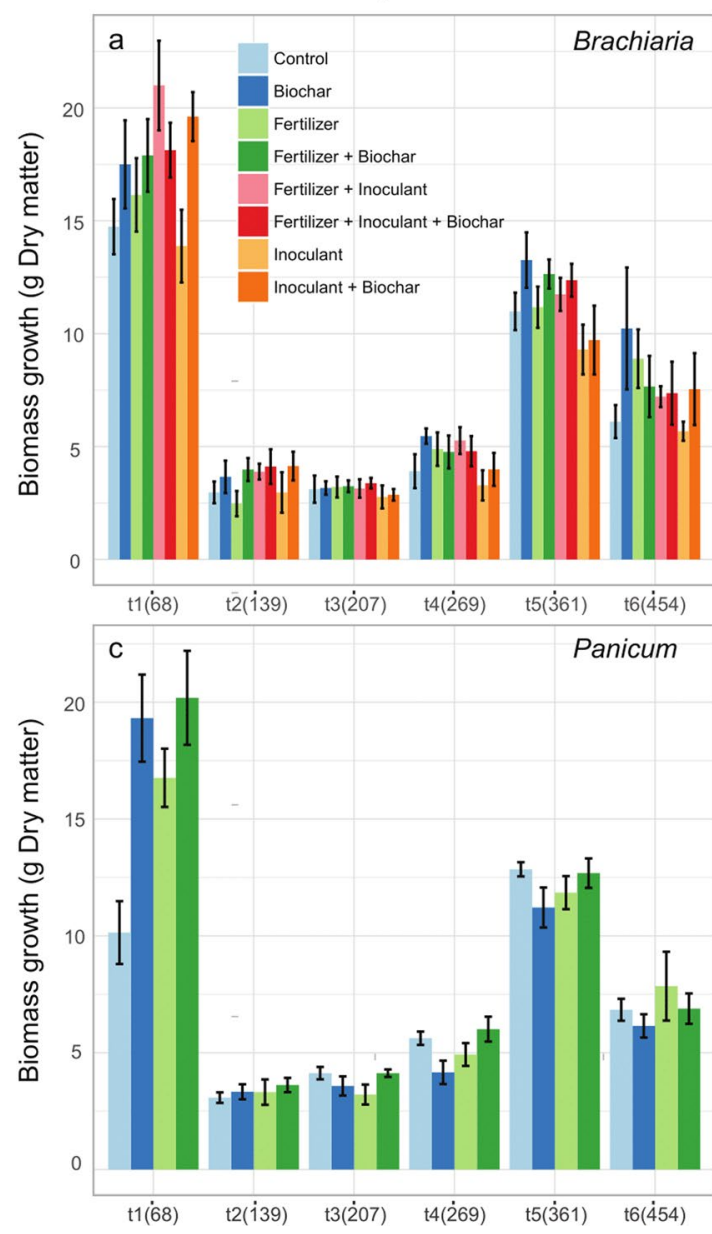

Total yield

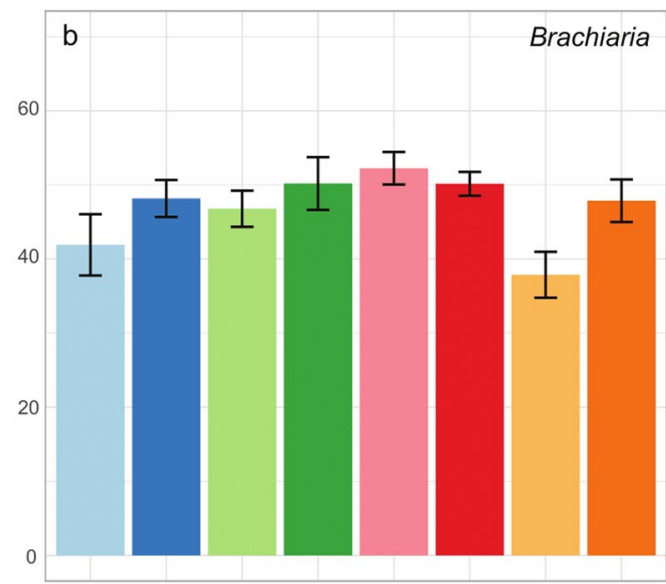

d

Panicum

60

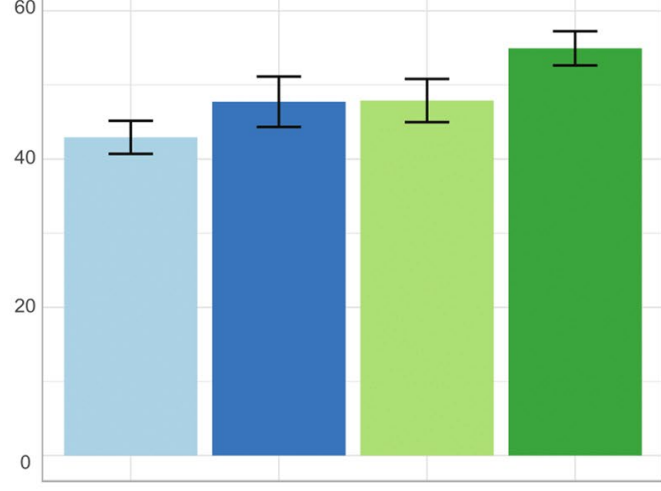

Figure 1. Aboveground biomass was harvested in six different times $(68,139,207,269,361$ and 454 days after planting). Left panels $(\mathbf{a}, \mathbf{c})$ show the yield in each of the harvests, and the right panels $(\mathbf{b}, \mathbf{d})$ show the total yield of the experiment. Vertical lines above each bar show the standard error.

their interactions on the two first axes of a PCA on root nutrient parameters (Supplementary Tables S10 and S11; Supplementary Fig. S4). In the field trials, we found similar patterns for leaf nutrient concentration (although only for Brachiaria), in which treatments with biochar tended to have higher leaf concentrations of K but lower of Mn, Mg and Ca (Supplementary Tables S12 and S13; Supplementary Fig. S5).

Soil properties. Figure 4 presents the results of a PCA on soil parameters performed at the end of the pot experiment for Brachiaria and Panicum. Loadings of the variables included in the PCA are in Supplementary Table S14. The first axis of the PCA (PC1) explained 50.1\% of the variation in the original dataset, and was positively correlated mainly with $\mathrm{Fe}, \mathrm{Al}, \mathrm{H}+\mathrm{Al}$ and $\mathrm{m}$ and negatively correlated mainly with $\mathrm{K}, \mathrm{P}, \mathrm{Ca}, \mathrm{Na}, \mathrm{Ca}, \mathrm{Mg}$, base sums, cation exchange capacity and pH (Fig. 3; Supplementary Table S14). The second axis (PC2) explained only $9.1 \%$ of the variation and was weakly positively correlated with $\mathrm{Zn}$ (Fig. 4, Supplementary Table S14). Biochar had a strong effect on axis PC1 for both grasses (Brachiaria: $\mathrm{t}=-7.74, \mathrm{p}<0.001 ;$ Panicum: $\mathrm{t}=-7.48$, $\mathrm{p}<0.001$; Table 3), which is also visible on Fig. 4, because soils on treatments with biochar tended to become less acidic, with increased levels of most macro and micronutrients, and lower levels of $\mathrm{Al}$ and Fe. Treatment effects on axis PC2 were weaker and less consistent (as this axis is not strongly correlated with any of the variables and explains little variation in the dataset): for Brachiaria, treatments with biochar showed lower values along this axis $(\mathrm{t}=-2.94, \mathrm{p}=0.006$; Table 3), while for Panicum treatments with either biochar or fertilizer shower higher values along this axis (biochar: $\mathrm{t}=3.26, \mathrm{p}=0.005$; fertilizer: $\mathrm{t}=3.97, \mathrm{p}=0.001$; Table 3 ). In the field trials, we found similar although weaker effects on soil properties, in which treatments with biochar showed higher levels of Ca, $\mathrm{Mg}$, base sums, $\mathrm{t}$ and P-resin (for Brachiaria) or higher $\mathrm{pH}$ (for Panicum; Supplementary Fig. S6; Supplementary Tables S15 and S16).

Cost-benefit analysis and ecosystem services valuation. Based on the average differences in biomass production of each treatment relative to the control, the additional meat production during the experiment period ( 454 days $=15$ months) $(\mathrm{t} / \mathrm{ha})$ and additional profits to the farmer were calculated taking into account forage productivity and meat price (Supplementary Table S17). 


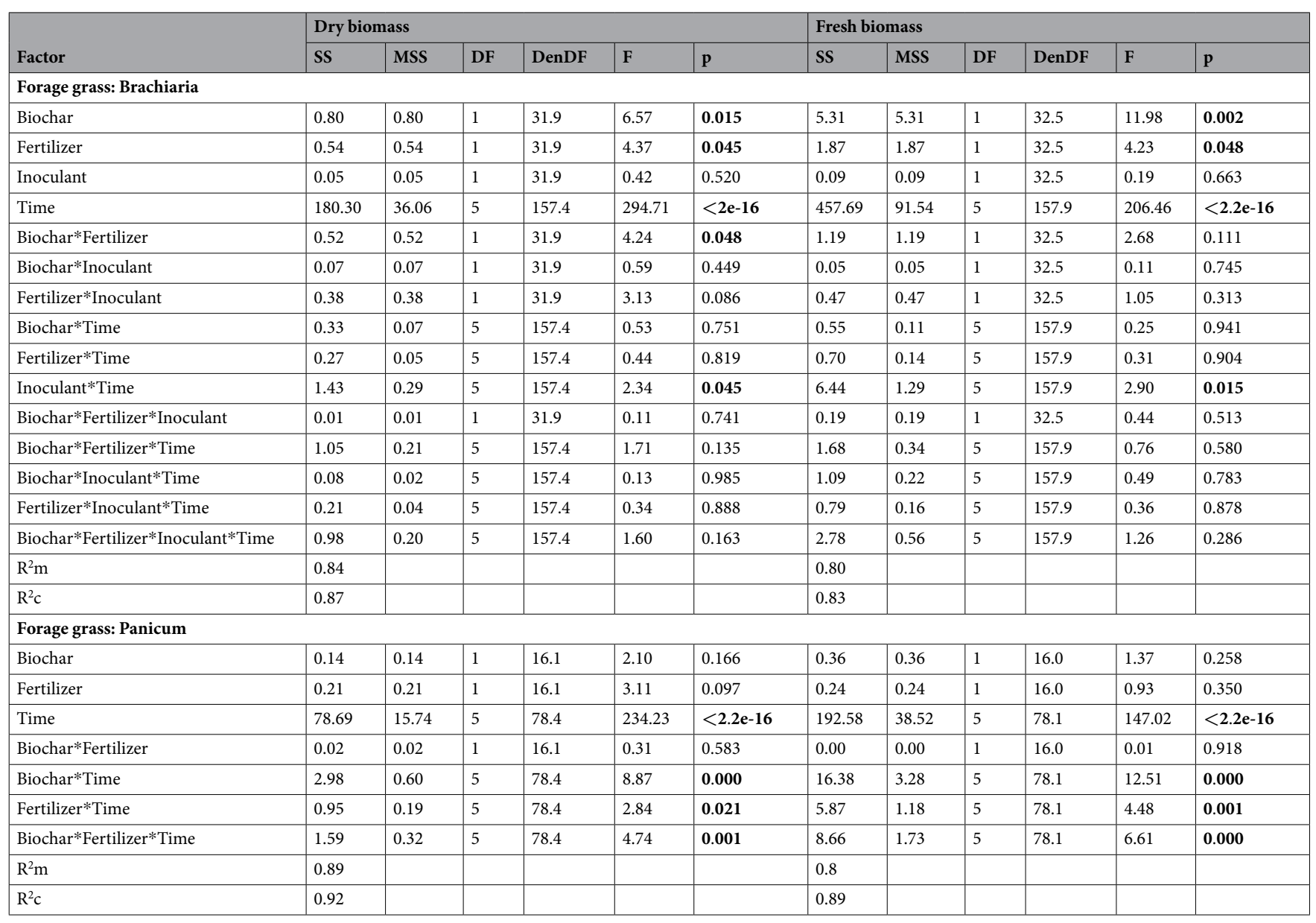

Table 1. Results of mixed effect models with six repeated measures on the effects of Biochar, Fertilizer and Inoculant (for Brachiaria only) (and their interactions) on the dry and fresh biomass of Brachiaria and Panicum forage grasses in a pot experiment. SS - sum of squares; MSS - mean sum of squares; DF - degrees of freedom; $\mathrm{R} 2 \mathrm{c}$ - conditional R2; R2m - marginal R2.

The highest additional meat production and profit was observed for the treatment with biochar (between US $\$ 191$ and US $\$ 324 /$ ha), followed by the combination of fertilizer with inoculant (between US\$172 and US\$295/ ha) and biochar with fertilizer (between US\$139 and US\$237; Supplementary Table S17). The treatment with only inoculant had a negative impact on biomass and consequently on profits when compared to the control.

If the biochar was produced for charcoal or other industrial purposes instead of being amended to the soil, farmers could additionally profit between US\$30 and US\$85 per month, considering the maximum of number of kilns that can be operated simultaneously without the necessity of additional labour. However, biochar production costs are high when juxtaposed either with increased productivity or profit from direct sale. To prepare enough biochar to apply in one hectare at the doses in our experiment (15t/ha), between 150 and 583 operating stoves (depending on the type) would be necessary and between 75 and 210 people to operate those stoves. At the same time, the profit generated by the sale during the experiment period, in full operation of the stoves, without falling yield and without stove maintenance in that period, the revenues by biochar sale would be lower than the costs, covering only between about 8 to $22 \%$ of total costs. Applying to the soil $15 \mathrm{t} /$ ha of biochar costs US $\$ 6,410$, while $682.5 \mathrm{~kg} / \mathrm{ha}$ of fertilizer would cost US\$ 893 , and $10 \mathrm{~kg} / \mathrm{ha}$ of inoculant would cost US $\$ 473$ and $3 \mathrm{t} / \mathrm{ha}$ of lime US\$74 (Fig. 5). Given increased productivity following the use of biochar (27\%) and fertilizer (12\%), fertilizer is $618 \%$ less expensive than biochar, assuming just one application of each amendment as performed in the experiment.

Regarding sequestered carbon, each hectare intensified with biochar is associated with US\$455 worth of carbon from land sparing effect. Given land intensification targets of the state of Rio de Janeiro $\left(180000 \mathrm{ha}^{35}\right)$, this may result in 16383832 tonnes of $\mathrm{CO}_{2}$ eq saved with the value of US\$ 82 million. If additional sequestration of carbon in soil from biochar use per hectare is considered (13 tonnes $\mathrm{CO}_{2} \mathrm{eq} / \mathrm{ha}$ ), the final estimates are 18714688 $\mathrm{CO}_{2}$ eq worth US\$ 94 million. Although GHG from biochar production were not considered in our study due to practical reasons, other publications report that biochar produced in simple stoves such as those used in our study contribute to minimizing GHG emissions ${ }^{36}$.

We also calculated the NPV based on the data from our study. Considering either the minimum or the maximum additional profit from biochar use, the NPV is negative and therefore economically unviable. The values 


\begin{tabular}{|c|c|c|c|c|c|c|c|c|c|c|c|}
\hline & \multirow[b]{2}{*}{ Harvest } & \multicolumn{7}{|c|}{ Brachiaria } & \multicolumn{3}{|c|}{ Panicum } \\
\hline & & B & F & $B+F$ & $\mathbf{F}+\mathbf{I}$ & $\mathbf{B}+\mathbf{F}+\mathbf{I}$ & I & B + I & B & $F$ & $\mathbf{B}+\mathbf{F}$ \\
\hline \multicolumn{12}{|l|}{ Dry matter } \\
\hline \multirow{8}{*}{$\begin{array}{l}\text { Average } \\
\text { Cumulative } \\
\text { difference }\end{array}$} & 1 & 18,7 & 9,6 & 21,4 & 42,4 & 23,0 & $-5,8$ & 33,1 & 90,5 & 65,3 & 99,1 \\
\hline & 2 & 23,3 & $-16,8$ & 34,1 & 30,9 & 38,6 & $-0,1$ & 39,3 & 8,2 & 7,7 & 17,6 \\
\hline & 3 & 1,7 & 3,0 & 4,1 & 1,0 & 8,4 & $-11,1$ & $-8,1$ & $-13,3$ & $-22,2$ & 0,0 \\
\hline & 4 & 39,7 & 25,0 & 21,8 & 34,7 & 22,7 & $-16,0$ & 2,0 & $-26,0$ & $-12,4$ & 6,9 \\
\hline & 5 & 20,7 & 1,7 & 15,1 & 6,9 & 12,6 & $-15,4$ & $-11,6$ & $-12,7$ & $-7,8$ & $-1,3$ \\
\hline & 6 & 67,5 & 45,5 & 25,4 & 18,0 & 20,6 & $-7,0$ & 23,5 & $-10,1$ & 14,7 & 0,7 \\
\hline & & 28,6 & 11,3 & 20,3 & 22,3 & 21,0 & $-9,2$ & 13,0 & 6,1 & 7,6 & 20,5 \\
\hline & & 27,4 & 11,8 & 20,0 & 24,9 & 19,9 & $-9,5$ & 14,4 & 11,9 & 12,3 & 25,5 \\
\hline \multicolumn{12}{|l|}{ Fresh matter } \\
\hline \multirow{8}{*}{$\begin{array}{l}\text { Average } \\
\text { Cumulative } \\
\text { difference }\end{array}$} & 1 & 15,4 & 8,8 & 19,9 & 41,9 & 33,8 & $-0,7$ & 44,1 & 128,0 & 90,2 & 135,4 \\
\hline & 2 & 19,7 & $-4,3$ & 24,4 & 30,9 & 31,1 & $-1,8$ & 44,9 & 7,8 & 5,0 & 12,6 \\
\hline & 3 & 11,6 & 3,6 & 22,7 & $-1,1$ & 25,1 & $-11,6$ & 2,9 & $-5,1$ & $-15,9$ & $-0,2$ \\
\hline & 4 & 44,2 & 14,2 & 33,1 & 14,2 & 26,9 & $-13,5$ & $-2,8$ & $-25,1$ & $-26,0$ & 0,1 \\
\hline & 5 & 19,8 & 15,8 & 16,7 & 16,3 & 27,0 & $-5,7$ & 39,4 & $-19,5$ & $-2,2$ & $-15,1$ \\
\hline & 6 & 31,8 & 31,1 & 18,7 & 6,5 & 32,9 & $-15,1$ & 22,3 & $-8,6$ & 13,1 & 5,8 \\
\hline & & 23,8 & 11,5 & 22,6 & 18,1 & 29,5 & $-8,1$ & 25,2 & 12,9 & 10,7 & 23,1 \\
\hline & & 22,4 & 10,6 & 22,4 & 24,3 & 30,6 & $-6,4$ & 28,9 & 21,9 & 15,6 & 32,9 \\
\hline
\end{tabular}

Table 2. Percent differences between treatments and control regarding dry and fresh matter of two forage grasses (Brachiaria and Panicum) in the pot experiment in a full factorial design. Measurements were taken at six different times ('harvests'). B - biochar; F - fertilizer; I - Inoculant.

ranged from $-5,705$ to $-5,572$. We also performed a simulation for financing of a biochar addition using the available fund from Low Carbon Agriculture Plan (Agricultura de Baixo Carbono, in Portuguese, ABC Plan ${ }^{35}$ ). Considering the biochar production costs at $15 \mathrm{t} / \mathrm{ha}$ rate and three different scenarios to estimate the minimum value of the carbon price we found that carbon price would need to range from US\$ 53.09 to US\$ 78.72 to make biochar use economically viable.

\section{Discussion}

Good pasture quality is fundamental for food production and initiatives to improve pasture quality have been promoted by public and private sectors ${ }^{6,37}$. Intensification of cattle ranching is happening in vast areas of Brazilian pasturelands but the question on how this intensification should be performed in the most sustainable way remains ${ }^{4}$. Results from this study show that incorporating biochar into pastureland soil could improve pasture productivity and positively impact a range of indicators for forage and soil quality. It could also contribute to better waste management since Gliricidia is one of residue biomass sources in Brazil such as Sabiá (Mimosa caesalpiniaefolia) or residues from pruning. Considering farmers' practice in Brazil who already apply charred residues into soil, and given that burning of organic residues is common throughout rural areas, biochar production could offer an alternative to business-as-usual (see video associated with this paper).

The increase in biomass productivity seen here can be ascribed to the positive changes in soil properties. A significant increase in soil $\mathrm{pH}$ in the treatments containing biochar was observed for both pot and field trials, and is consistent with other studies that have been carried out on acidic degraded soils ${ }^{37,38}$. High acidity of degraded pasturelands is one of the principal limitations to increasing cattle ranching productivity. Biochar provides not only a liming effect, but also increases the content of macronutrients such as $\mathrm{P}$ and $\mathrm{K}$ as was observed for both forages in both the pot and field experiments. However, other macronutrients such as $\mathrm{Ca}$ and $\mathrm{Mg}$, although also increased in the soils where biochar was added, decreased in the forage biomass in treatments with biochar. This could be explained by a dilution effect given the higher volumes of biomass (Supplementary Fig. S6) or a antagonistic effect where high $\mathrm{K}$ absorption could have interfered with the capacity of grasses to absorb other cations $^{39}$. Treatments with fertilizer did not provide prolonged fertilization effect with respect to $\mathrm{Mg}$ and in Brazil, cattle are universally fed magnesium supplements to avoid bone fractures. In this study the positive interaction between biochar and fertilizer observed for Panicum corroborates the results from literature that have shown that to maximize biochar effect on agricultural productivity of selected plants, biochar should be used in combination with fertilizer ${ }^{40}$.

Different results were obtained for the pot and field studies. Although patterns observed in the field for some soil parameters ( $\mathrm{pH}, \mathrm{K}$ and $\mathrm{P}$ contents) and biomass nutrient contents were consistent with the results from the pot experiment, the increases in aboveground biomass yield in the pot trial were not observed in the field. The results of the field trials, however, must be interpreted with caution, given that the plots were relatively small $(2 \times 2 \mathrm{~m})$, with few replicates and less harvests. Although the field experiment was initially planned to last six harvest cycles (as for the pot trial), it had to be ended sooner due to severe drought, fire risk and forage shortage for neighbouring cattle. The field trials enabled surveying practical aspects of biochar, such as time and costs involved in biochar production in different types of stoves and field application; aspects which are paramount for implementation of biochar use in practice and its economic and social viability. 


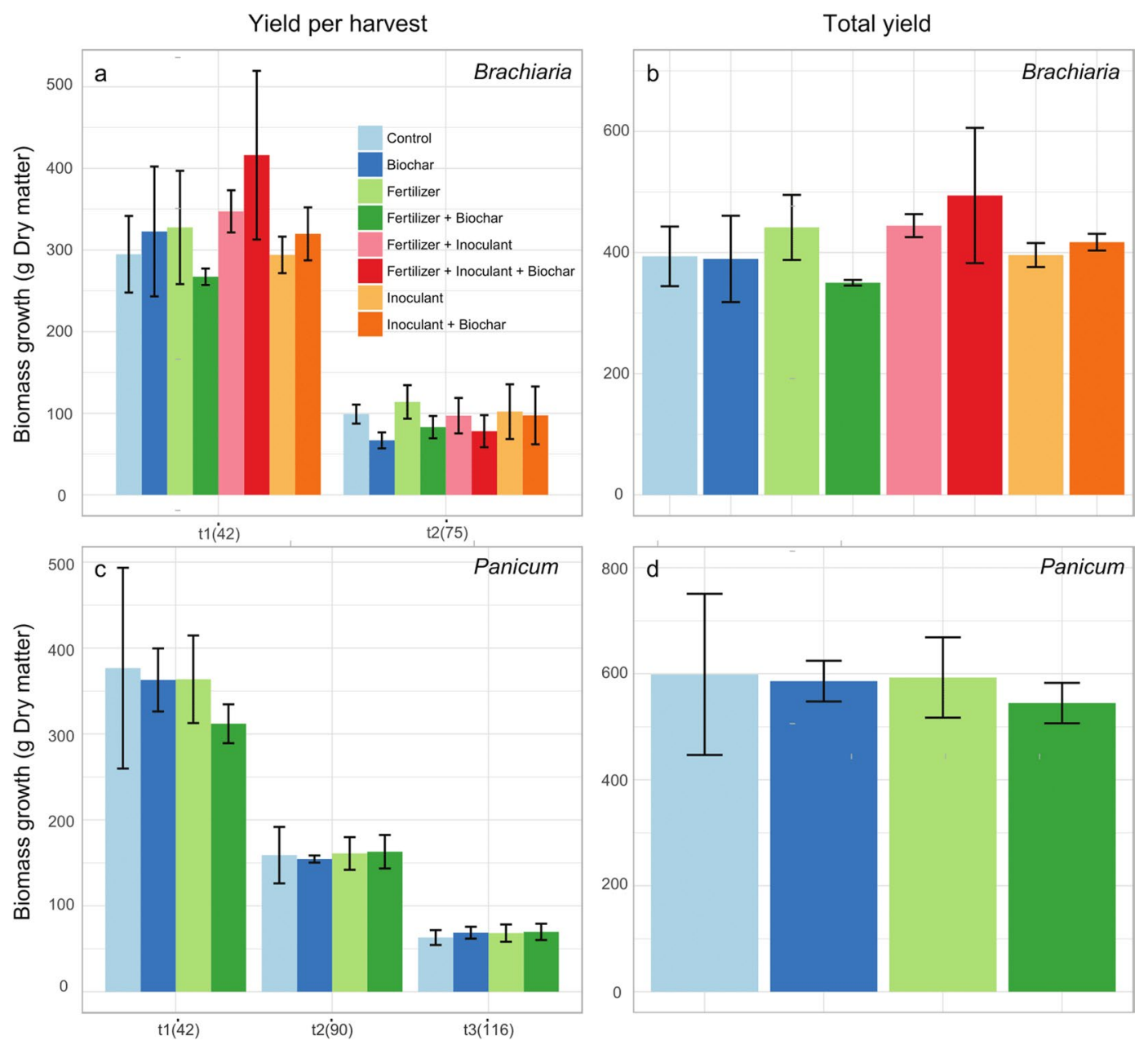

Figure 2. Aboveground biomass was harvested in two or three different times (42 and 75 days after planting for Brachiaria, and 42,90 and 116 after planting for Panicum) in the field trial. Left panels (a,c) show the yield in each of the harvests, and the right panels $(\mathbf{b}, \mathbf{d})$ show the total yield of the trial. Vertical lines above each bar show the standard error.

Despite literature stating that biochar may be a low-cost soil amendment with a high adoption potential for local farmers ${ }^{41}$, few studies present comprehensive analyses that support such claims. Here we show that although on-farm methods to produce biochar are simple and do not require sophisticated equipment to be installed and run, when the labour costs are taken into account, biochar application at the rate considered in this study is not competitive when compared with other soil amending alternatives. Even with the significant increase in the pasture productivity following the application of biochar and potential additional profits to the farmers with increased meat production, financial viability to produce and apply biochar for a small to medium size farmland remains a great challenge. This is not uncommon for emerging technologies, but the need for further research and investment should be highlighted and the use of biochar in practice should not be promoted without full transparency and a thorough cost-benefit analysis. Possible alternatives to diminish costs are using commercially produced biochar, applying biochar at lower doses (depending whether productivity increase will follow) or using biochar for a more profitable land use, as it is difficult for a small to medium-holder farmers to be economically viable when cattle ranching for meat production is considered ${ }^{42}$. Given additional benefits from biochar use such as carbon sequestration, farmers could also benefit from Payments for Ecosystem Services to leverage the costs and contribute to global goals to combat climate change. If payments for carbon were used to subsidize biochar use, carbon price would need to range from US\$ 53.09 to US\$ 78.72. Interestingly, to achieve the goals of the Paris Agreement, the carbon price would have to be in the range of US\$ 40 to US\$ 80 in 2020 and US\$ 50 to US\$100 in $2030^{43}$. In Brazil, one of the possibilities for encouraging the use of biochar would be through 'Low Carbon Agriculture' funding, since biochar is one of the possibilities for improving soil quality and may contribute to the reduction of greenhouse gases.

Improving land management of Brazilian farmlands is important because local and global ecosystem services should be maintained and deforestation of remaining native ecosystems should be limited ${ }^{44}$. Since smallholder farmers often search for alternative methods to increase productivity and reverse land degradation, biochar could help improving soil properties while increasing the provision of other important ecosystem services. Here, food 

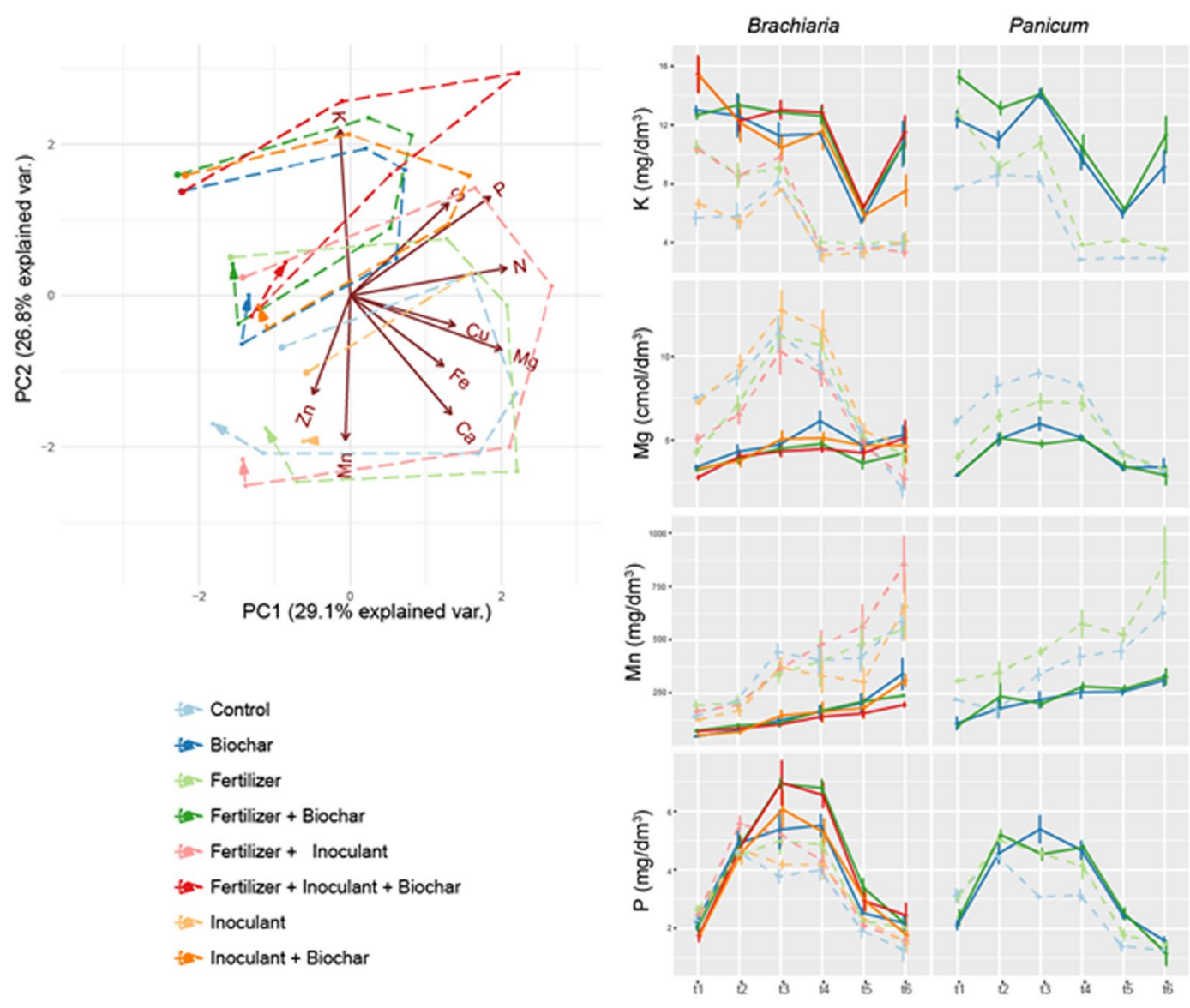

Figure 3. Left panel: Principal Components Analysis of foliar nutrient concentration, measured in a pot experiment with two forage grasses (Brachiaria and Panicum). Foliar nutrient concentration was measured in six different times (harvests). Each point in the figure represents the centroid of five replicates (pots) measured at a given time, their colors indicate the different treatments and the dashed lines connecting the centroids indicate the changes in nutrient contents through time (harvests), with arrows indicating nutrient contents measured at the last harvest. Vectors indicate the soil variables included in the PCA, and their length and direction indicate the magnitude and direction in which they contribute to the ordination, respectively. Values between brackets indicate the percentage of the variation in the original dataset that is explained by axes PC1 and PC2. Right panel: variation of selected foliar nutrients through time, in the same pot experiment.

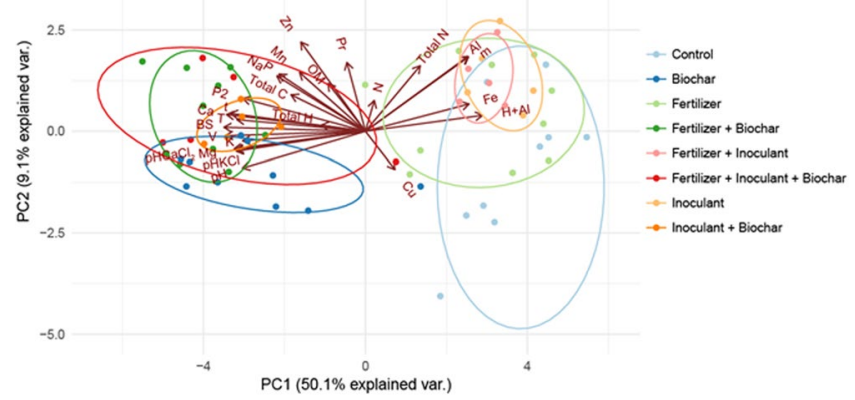

Figure 4. Principal Components Analysis of soil chemical parameters measured in a greenhouse experiment with two forage grasses (Panicum and Brachiaria). Each point in the figure represents a replicate (pot), and their colors indicate the different treatments. Vectors indicate the soil variables included in the PCA, and their length and direction indicate the magnitude and direction in which they contribute to the ordination, respectively. Values between brackets indicate the percentage of the variation in the original dataset that is explained by axes PC1 and PC2. 


\begin{tabular}{|l|l|l|l|l|l|l|l|l|l|}
\hline \multirow{2}{*}{ Treatment } & Axis PCA1 & \multicolumn{7}{|l|}{ Axis PCA2 } \\
\cline { 2 - 9 } & Est. & SE & t & p & Est. & SE & t & p \\
\hline Forage grass: Brachiaria & 4.351 & 0.574 & 7.58 & 0.000 & 0.437 & 0.395 & 1.11 & 0.277 \\
\hline Intercept & -6.285 & 0.812 & -7.74 & $\mathbf{0 . 0 0 0}$ & -1.640 & 0.559 & -2.94 & $\mathbf{0 . 0 0 6}$ \\
\hline Biochar & -0.632 & 0.812 & -0.78 & 0.442 & 0.904 & 0.559 & 1.62 & 0.116 \\
\hline Fertilizer & -0.997 & 0.812 & -1.23 & 0.228 & 0.938 & 0.559 & 1.68 & 0.103 \\
\hline Inoculant & -1.399 & 1.148 & -1.22 & 0.232 & 0.365 & 0.790 & 0.46 & 0.647 \\
\hline Biochar*Fertilizer & -0.188 & 1.148 & -0.16 & 0.871 & 0.426 & 0.790 & 0.54 & 0.593 \\
\hline Biochar*Inoculant & 0.204 & 1.148 & 0.18 & 0.860 & -0.970 & 0.790 & -1.23 & 0.228 \\
\hline Fertilizer*Inoculant & 1.781 & 1.624 & 1.10 & 0.281 & -0.077 & 1.117 & -0.07 & 0.945 \\
\hline Biochar*Fertilizer*Inoculant & & & & & & & & \\
\hline Forage grass: Panicum & 3.318 & 0.651 & 5.10 & 0.000 & -3.198 & 0.494 & -6.48 & 0.000 \\
\hline Intercept & -6.882 & 0.920 & -7.48 & $\mathbf{0 . 0 0 0}$ & 2.278 & 0.698 & 3.26 & $\mathbf{0 . 0 0 5}$ \\
\hline Biochar & -1.197 & 0.920 & -1.30 & 0.212 & 2.774 & 0.698 & 3.97 & $\mathbf{0 . 0 0 1}$ \\
\hline Fertilizer & 0.728 & 1.301 & 0.56 & 0.584 & -1.177 & 0.987 & -1.19 & 0.251 \\
\hline Biochar*Fertilizer & & & & & & &
\end{tabular}

Table 3. Results of generalized linear models showing the effects of biochar, fertilizer and inoculant (and their interactions) on soil chemical parameters measured in a greenhouse experiment with two forage grasses (Panicum and Brachiaria). PCA1 and PCA2 are the first two axes of a Principal Components Analysis summarizing the variation in soil parameters, explaining 50.1 and $9.1 \%$ of the original variation in soil parameters, respectively. Est - estimated coefficient; SE - Standard error of the estimate. Significant p-values are highlighted in bold.

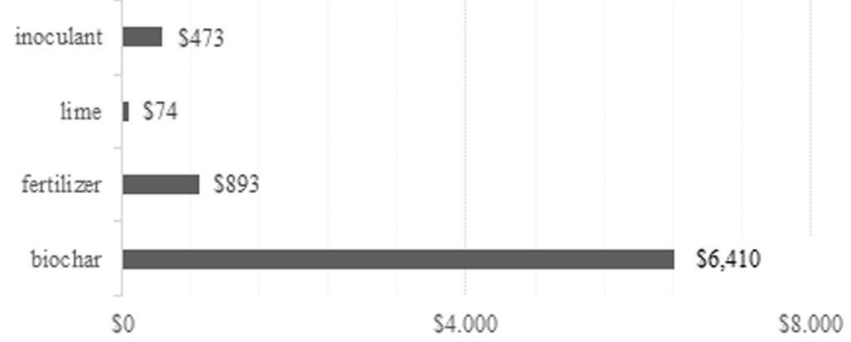

Figure 5. Comparison of the costs, in US\$, of each treatment used in the experiment associated with forage grasses Brachiaria. For each treatment, represented in each bar of the graph, the cost in dollars was estimated considering that $15 \mathrm{t}$ of biochar, $10 \mathrm{~kg}$ of inoculant, $3 \mathrm{t}$ of limestone and $682.5 \mathrm{~kg}$ of fertilizer were used for each experiment with the forage grass, Brachiaria.

production and carbon sequestration were valued as they reflect soil provisioning and regulating services, respectively. There are other potential ecosystem services stemming from biochar use which were not valuated here, such as supporting service of nutrient cycling (shown in our experiments through increases in $\mathrm{P}, \mathrm{K}, \mathrm{Ca}, \mathrm{Mg}$, for example) and regulating service through liming effect and increase in soil $\mathrm{pH}$. Another crucial ecosystem service is water provision, and although biochar has been shown to improve water retention ${ }^{44}$ this was not observed in our study. It is important therefore that researchers analyse the extent to which biochar can contribute to a wider range of soil ecosystem services, as to date such analysis remain overlooked. Adequate and comprehensive valuation of biochar ecosystem services is largely excluded from published studies and environmental impact assessments and therefore rarely considered in decision-making and environmental policies. This study has highlighted the importance of considering biochar in the context of ecosystem services to better estimate biochar potential costs and benefits, and its place in wider context of soil contribution to human well-being.

\section{References}

1. Steinfeld, H. et al. Livestock's Long Shadow: Environmental Issues and Options. Food and Agriculture Organization of United Nations (FAO), Rome (2006).

2. Galdino S. et al. Large-scale Modeling of Soil Erosion with RUSLE for Conservationist Planning of Degraded Cultivated Brazilian Pastures. Land Degradation and Development 27, https://doi.org/10.1002/ldr.2414, (2016).

3. Strassburg, B. B. N. et al. When enough should be enough: Improving the use of current agricultural lands could meet production demands and spare natural habitats in Brazil. Glob. Environ. Chang. 28, https://doi.org/10.1016/j.gloenvcha.2014.06.001 (2014).

4. Latawiec, A. E., Strassburg, B. B. N., Brancalion, P. H. S., Rodrigues, R. R. \& Gardner, T. Creating space for large-scale restoration in tropical agricultural landscapes. Frontiers in Ecology and the Environment 13(4), 211-218, https://doi.org/10.1890/140052 (2015).

5. Latawiec, A. E., Strassburg, B. B. N., Valentim, J. F., Ramos, F. \& Alves-Pinto, H. N. Intensification of cattle ranching production systems: Socioeconomic and environmental synergies and risks in Brazil. Animal (Cambridge. Print) 8, 1255-1263, https://doi. org/10.1017/S1751731114001566 (2014). 
6. Latawiec, A. E. et al. Improving land management in Brazil: A perspective from producers. Agriculture Ecosystems \&. Environment 240, 276-286, https://doi.org/10.1016/j.agee.2017.01.043 (2017).

7. Zu Ermgassen, E. et al. Results from on-the-ground efforts to promote sustainable cattle ranching in the Brazilian Amazon. Sustainability (Switzerland) 10(4), https://doi.org/10.3390/su10041301(2018).

8. Macedo, M. C. M. Sistemas de produção em pasto nas savanas da América Tropical: limitações e sustentabilidade. In: Reunión Latino Americana de Produccion Animal, 16. Congresso uruguayo de produccion animal, 3. Montevideo, UR. Anales. Montevideo, UR (CD-ROM) (2000).

9. Strassburg, B. B. N. et al. Impacts of incentives to reduce emissions from deforestation on global species extinctions. Nat. Clim. Chang. 2, 350-355, https://doi.org/10.1038/NCLIMATE1375 (2012).

10. OECD/FAO. Agricultural Outlook 2016-2025, OECD Publishing, Paris, https://doi.org/10.1787/agr_outlook-2016-en (2016).

11. UK Government Office for Science. Foresight Project on Global Food and Farming Futures - Synthesis Report C1: Trends in food demand and production, http://webarchive.nationalarchives.gov.uk/20121204181824/http://bis.gov.uk/assets/foresight/docs/foodand-farming/synthesis/11-621-c1-trends-food-demand-and-production.pdf (2011).

12. BRAZIL/MMA. Plano Nacional de recuperação da vegetação nativa, http://snif.florestal.gov.br/images/pdf/publicacoes/planaveg_ publicacao.pdf (2013)

13. Sparovek, G., Berndes, G., Barreto, A. G. O. P. \& Klug, F. The revision of the Brazilian Forest Act: increased deforestation or a historic step towards balancing agricultural development and nature conservation? Environmental Science \& Policy 16, 65-72, https://doi. org/10.1016/j.envsci.2011.10.008 (2011).

14. Soares-Filho, B., Rajão, R. \& Macedo, M. Cracking Brazil's Forest Code. Science 344(6182), 363-364, https://doi.org/10.1126/ science.1246663 (2014)

15. Maes, J. et al. Mapping ecosystem services for policy support and decision making in the European Union. Ecosystem Services 1(1), 31-39, https://doi.org/10.1016/j.ecoser.2012.06.004 (2012).

16. Adhikari, J. \& Hartemink, A. E. Linking soils to ecosystem services - A global review. Geoderma 262(15), 101-111, https://doi. org/10.1016/j.geoderma.2015.08.009 (2016).

17. Lehmann, J. \& Joseph, S. Biochar for environmental management: An introduction in Biochar for Environmental Management Science and Technology (eds Lehmann, J. \& Joseph, S) (Earthscan, 2009).

18. Lehmann, J., Kuzyakov, Y., Pan, G. \& Ok, Y. S. Biochars and the plant-soil interface. Plant and Soil 395, 1-5, https://doi.org/10.1007/ s11104-015-2658-3 (2015).

19. Rabileh, M. A., Shamshuddin, J., Panhwar, Q. A., Rosenani, A. B. \& Anuar, A. R. Effects of biochar and/or dolomitic limestone application on the properties of Utisol cropped to maize under glasshouse conditions. Canadian Journal of Soil Science 95(1), 1-11, https://doi.org/10.4141/cjss-2014-067 (2015).

20. Castro, A. et al. The effects of Gliricidia-derived biochar on sequential maize and bean farming. Sustainability 10(3), 578, https://doi. org/10.3390/su100030578 (2018).

21. Novotny, E. H., Maia, C. M. B. F., Carvalho, M. T. M. \& Madari, B. E. Biochar: pyrogenic carbon for agricultural use - a critical review. Revista Brasileira de Ciência do Solo 39(2), 321-344, https://doi.org/10.1590/01000683rbcs20140818 (2015).

22. Slavich, P. G. et al. Contrasting effects of manure and green waste biochars on the properties of an acidic ferralsol and productivity of a subtropical pasture. Plant Soil 366, 213-227 (2013).

23. Wang, J., Xiong, Z. \& Kuzyakov, Y. Biochar stability in soil: meta-analysis of decomposition and priming effects. GCB Bioenergy 8 , 512-523, https://doi.org/10.1111/gcbb.12266 (2016).

24. FAO. World Reference Base for Soil Resources (1998).

25. Pennise, D. M. et al. Emissions of greenhouse gases and other airborne pollutants from charcoal making in Kenya and Brazil. Journal of Geophysical Research: Atmospheres 106(D20), 24143-24155 (2001).

26. Martinsen, V. et al. Farmer-led maize biochar trials: Effect on crop yield and soil nutrients under conservation farming. J. Plant. Nutr. Soil Sci. 177(5), 681-95, https://doi.org/10.1002/jpln.201300590 (2014).

27. Malavolta, E., Vitti, G. C. \& Oliveira, S. A. Avaliação do estado nutricional das plantas: princípios e aplicações. Piracicaba: Associação Brasileira para Pesquisa da Potassa e do Fosfato (Potafos) (1997).

28. R Development Core Team, R. A language and environment for statistical computing. R Foundation for Statistical Computing, Version 3.5.1. (2018).

29. Bates, D., Maechler, M., Bolker, B. M. \& Walker, S. C. Fitting linear mixed-effects models using lme4. Journal of Statistical Software 67(1), 1-48, https://doi.org/10.18637/jss.v067.i01 (2015).

30. Barton, K. Multi-Model Inference. R package version 1.42.1, https://CRAN.R-project.org/package=MuMIn (2018).

31. Empresa Brasileira de Pesquisa Agropecuária (Embrapa). Projeto PECUS, https://www.embrapa.br/busca-de-projetos/-/ projeto/38444/projeto-da-rede-pecus (2018).

32. Valadares Filho, S. C., Magalhães, K. A., Rocha Júnior, V. R. \& Cappelle, E. R. Tabelas brasileiras de composição de alimentos para bovinos ( $e^{\circ}$ ed.) Viçosa, Brasil (2015).

33. Companhia Nacional de Abastecimento (Conab). Preços de mercado, http://sisdep.conab.gov.br/precosiagroweb/ (2018).

34. Instituto de Economia Agrícola - Estado de São Paulo, www.iea.agricultura.sp.gov.br (2018).

35. Governo do Estado do Rio de Janeiro. Plano ABC - Plano Estadual de Mitigação e de Adaptação as Mudanças Climáticas, http:// www.ri.gov.br/c/document_library/get_file?uuid=82b929ed-74e5-40ce-aclf-6f249e5971d5\&groupId=132950 (2018).

36. Pandit, N. R., Mulder, J., Hale, S. E., Schmidt, H. P. \& Cornelissen, G. Biochar from "Kon Tiki” flame curtain and other kilns: Effects of nutrient enrichment and kiln type on crop yield and soil chemistry. PLoS One 12(4), e0176378, https://doi.org/10.1371/journal. pone.0176378 (2017).

37. Jien, S. \& Wang, C. Effects of biochar on soil properties and erosion potential in a highly weathered soil. Catena 110, 225-233, https://doi.org/10.1016/j.catena.2013.06.021 (2013).

38. Cornelissen, G. et al. Biochar effect on maize yield and soil characteristics in five conservation farming sites in Zambia. Agronomy 3(2), 256-274, https://doi.org/10.3390/agronomy3020256 (2013).

39. Sparrevik, M., Adam, C., Martinsen, V. \& Cornelissen, G. Emissions of gases and particles from charcoal/biochar production in rural areas using medium-sized traditional and improved "retort" kilns. Biomass and Bioenergy 72, 65-73, https://doi.org/10.1016/j. biombioe.2014.11.016 (2015)

40. Schmidt, H. P., Pandit, B. H., Cornelissen, G. \& Kammann, C. I. Biochar-based fertilization with liquid nutrient enrichment: 21 field trials covering 13 crop species in Nepal. Land Degradation \& Development 28(8), 2324-2342, https://doi.org/10.1002/ldr.2761 (2017).

41. Häring V. et al. Effects of biochar, waste water irrigation and fertilization on soil properties in West African urban agriculture. Scientific Reports 7(10738), https://doi.org/10.1038/s41598-017-10718-y (2017).

42. Strassburg, B. B. N. et al. The role of natural regeneration to ecosystem services provision and habitat availability: a case study in the Brazilian Atlantic Forest. Biotropica 48, 890-899, https://doi.org/10.1111/btp.12393 (2016).

43. World Bank. Report of the High-Lever Commission on Carbon Prices, https://static1.squarespace.com/ static/54ff9c5ce4b0a53decccfb4c/t/59b7f2409f8dce5316811916/1505227332748/CarbonPricing_FullReport.pdf (2017).

44. Foley, J. A. et al. Global consequences of land use. Science 309(5734), 570-574, https://doi.org/10.1126/science.1111772 (2005). 


\section{Acknowledgements}

We thank Ivana Vieira, Ilzo Artur Moreira Risso, Athayde Mendes Fernandes, Gabriel Galvão, Ederson da Conceição Jesus, Vandelucio José Santana, Katarzyna Korys and Luisa Lemgruber for their invaluable help in the field. The Norwegian Agency for Development Cooperation is gratefully acknowledged for their financial support. Gerard's Cornelissen personal stipend is gratefully acknowledged. Sarah E. Hale obtained funding from the Norwegian Research Council under the Klimaforsk program, project 243789, "Biochar as an adaptation strategy for climate change". We thank, Alvaro Iribarrem for the mathematical equation elaboration, Eric Lino for organizing the analytical methods of Soil Sampling and Analysis, and Carlos Leandro Cordeiro for producing the map of the Atlantic Forest biome with indication of potential areas for restoration; forest remnants; and original limits of the Atlantic Forest. We thank Isabella Leite and Ingrid Pena for their help with manuscript editing. Fernanda Gomes is gratefully acknowledged for the video recording and editing. We thank two anonymous Reviewers for their constructive comments. The revision of this paper was inspired by the workshops in Brazil and England in March and April 2019 within the project 'Sustaining the land from the ground up: developing soil carbon and soil ecosystem services valuation frameworks for tropical soils', funded by the Royal Society/Newton Advanced Fellowship Grant Number NAF\R2\180676.

\section{Author Contributions}

A.E.L. conceived the study; A.E.L., B.B.N.S., E.A., L.F.M., M.R., G.C., J.G.G., S.H. designed the research; A.E.L., E.A., H.A.N.P., A.C., M.R., A.F.R., M.M., N.S.B. performed the field experiments; A.E.L., B.B.N.S., A.B.J., G.M., A.F.R., E.H.N., E.Z., L.G.B. analyzed the data; A.E.L., A.B.J., H.A.N.P., G.M., A.F.R., C.J., E.H.N., G.C., E.Z., S.H. wrote the manuscript.

\section{Additional Information}

Supplementary information accompanies this paper at https://doi.org/10.1038/s41598-019-47647-x.

Competing Interests: The authors declare no competing interests.

Publisher's note: Springer Nature remains neutral with regard to jurisdictional claims in published maps and institutional affiliations.

(c) (i) Open Access This article is licensed under a Creative Commons Attribution 4.0 International License, which permits use, sharing, adaptation, distribution and reproduction in any medium or format, as long as you give appropriate credit to the original author(s) and the source, provide a link to the Creative Commons license, and indicate if changes were made. The images or other third party material in this article are included in the article's Creative Commons license, unless indicated otherwise in a credit line to the material. If material is not included in the article's Creative Commons license and your intended use is not permitted by statutory regulation or exceeds the permitted use, you will need to obtain permission directly from the copyright holder. To view a copy of this license, visit http://creativecommons.org/licenses/by/4.0/.

(C) The Author(s) 2019 